\title{
Using a Mobile-based Online Platform to Mentor Girls: Challenges and Benefits
}

\author{
Bukola Fakayode $^{1^{*}} \&$ Samantha Okegbe ${ }^{2}$
}

${ }^{1}$ Department of Science and Technology Education, University of Ibadan, Nigeria.

${ }^{2}$ Department of Communication, The University of Illinois Urbana-Champaign, Illinois.

Author email: sokegbe2@illinois.edu

Author full postal address: 6805 Townbrook Dr. Apt D, Gwynn Oak, Maryland, 21207.

\begin{abstract}
In some parts of Nigeria, many girls do not attend school, and among those sent to school, many still drop out early. This and other socio-cultural factors affect girls psychologically. There is no doubt that girls need consistent love and tutoring to guide them through the turbulent teen years and beyond. They need a mentor who acts as a friend and a role model. The Mobile-based Mentoring Platform seeks to leverage on mobile technology's affordances to focus on the needs of the girl-child, such as improvement in academic achievement, guidance in career choice, development of self-concept, and esteem. The girlmentees comments revealed that using the platform provided them frequent access to mentors and access to learning opportunities. The challenges they faced include epileptic internet network, intrusions by parents, and others. Therefore, this paper examined the challenges and benefits of mentoring girls via a mentoring platform.
\end{abstract}

Keywords: Mobile-based mentoring, girl-child, mentoring, mobile technology.

\section{Introduction}

Educating girls is one of the most important investments that any country can make. Any society's development will not be balanced if a girl child is not given the right kind of education. A girl today will be a mother tomorrow, and for this reason, educating girls is paramount to any nation's growth and development. No sustainable development is possible if women remain uneducated, discriminated against, and disenfranchised. Improving and widening access to education, especially basic education, is not only an objective in itself but also accelerates social and economic advancement (Fakayode, 2017). 
Challenges associated with educating the girl-child around the world have many dimensions. However, the root of all kinds of discrimination and bias against the girl child lies in the customs, traditions, and mindset of the society that considers the girl child and women as inferior beings. Women and girls have been treated in the most inhuman ways from human civilization's inception (Fisho-Orideji, 2001; Igube, 2004).

A report by Plan Canada indicated that 500 and 1.5 million children around the world experience violence every year, and 62 million girls around the world are not in school while millions more are fighting just to stay there (Plan Canada (2015)

Factors responsible for this include; the cost of education, distance to school, violence at school, gender norms, poverty, early marriage and, pregnancy. Most of the factors that militate against the girl-child access to education are socio-cultural (Offorma, 2008). 'Gender-biased educational processes, including curricula, educational materials and practices, factors attitude and classroom interaction, reinforce existing gender inequalities' (The United Nations, 1995).

Most African youths in Nigeria now experience sex at an earlier age than their parents (WHO, 2004). This view has also been corroborated by some studies which showed a decline in the age of sexual experience among adolescents contrary to accepted moral and cultural values (Osakwe, 1993; Okpani, 2002 ).

There is no doubt that this is a dangerous trend that affects the educational system and society. It is expected that the school will provide the necessary guidance through wholesome educational studies to ensure its future generation of leaders. Preventing avoidable deaths from illegal abortions by pregnant teenagers and dangerous sexually transmitted diseases can be achieved to no small extent through proper education and mentoring practice. Some actions and attitudes of these girls are psychological. They need someone to give them adequate support and guidance. Therefore, mentoring girls on issues peculiar to them can foster their understanding of how to go about their day-to-day activities. Mentoring occurs in a variety of contexts and for a variety of purposes. Mentoring relationships help guide young persons to develop career aspirations or general life skills and social support. Mentoring is most often defined as a relationship in which an experienced person (the mentor) assists another (the mentee) in developing specific skills and knowledge that will enhance the less-experienced person's professional and personal growth (Adedoja, Abimbade, Akinyemi, and Bello, 2017). Mentoring is a complex 
interaction between a trusted adult and a mentee partner; the interactions are psychological, professional, and personal by nature (Matthews, 2003).

The mentee can be guided on how to handle situations around her and conduct herself in a manner that is worthy of emulation. Mentoring is a relationship that occurs in a planned or unplanned situation, and, in most cases, not expected (Galbraith, 2001). A level of trust emerges between the mentor and the mentee drawing the two individuals together for professional, personal, and psychological development. Sometimes, schools or organizations can define the extent of the relationship and the timeframe in which mentoring will occur (Foster, Poole, and Coulson-Clark,2001).

Mother/Daughter program is a mentoring program that encourages Hispanic-American girls to seek higher education, especially those whose family members have not attended college. The program increased career option awareness of the girls, self-confidence and raised the young girls' educational aspiration. Big Brother/Big sister of America targeted disadvantaged youths between the ages of five and eighteen years who have no more than one active parent or guardian in their lives. This intervention improved the attitude of youths towards schooling and reduced their antisocial behavior tendencies. Also, Girl for Girl program helps girls from economically disadvantage families to speak out against physical abuse and harassment.

Mentoring gives girls the chance to spend time with a trusted adult who accepts them as they are. It inspires girls to do their best and helps them to succeed in every facet of life. During mentoring activities, girls can ask questions on issues that pertain to their health and sex, boyfriends, school work, and future goals and aspirations. The mentor can be almost anyone - a mother, young woman, religious leaders, or a professional woman in any field (Fakayode, 2017). The goal is to help girls to be bold, strong enough to state their rights, and free enough to rise to their full potential as they lead their country forward. When girls receive information through mentoring that will help them make good decisions about all aspect of their life, they are more likely to stay in school, take good care of themselves and be successful in future activities. Mentoring girls raises economic productivity of a nation and contributes to their improved health and nutrition, and increases the chances of education for the next generation (Adedoja, et al., 2017). 
The use of digital technologies in our day-to-day lives have made interactions and communication simpler and not restricted by space and time. Mobile technologies enable individuals (Teachers/Students, Mentors/Mentees) build a working relationship that is context-based and flexible (Adedoja and Abimbade, 2016).

The affordances of mobile technologies provide opportunities for mentoring relationships to be seamless. The core of mobile-based mentoring is to make mentors always available to the mentees (Fakayode, 2017). In this present study, mentors and mentees are able to interact on a platform domicile on www.mentoringinititative.org. The platform is designed to support Progressive Web App (PWA) so that web pages appear like traditional applications or native mobile applications to users. The hallmark of the mobile-based mentoring is to provide adequate support and guidance for girls on issues that pertain to academics, career, sex, generally life skills, relationships at school and home, job placement and others. This study examined the benefits and challenges girls experienced in using mobile-based mentoring platform. This study is part of a larger project that examines the impacts of mobile-based mentoring on girls' attitudes towards antisocial behaviors among secondary school students in Ibadan. Oyo state.

\section{Research Questions}

1. What are the benefits of using mobile-based mentoring for girls?

2. What are the challenges of using mobile-based mentoring for girls?

\section{Methodology}

This study is a qualitative research, there is no manipulation of variables, and the meaning of actions is obtained from specific questions. The researchers simply seek to examine the benefits and challenges of the mobile-based mentoring for girls. The researcher did not manipulate any variable but deductions are made based on evidence collected and not from responses occasioned.

\section{Instrument and Measures}

The Focus Group Discussion Guide was developed for this study in order to have in-depth information about the challenges and benefits of using the mentoring platform. The FGD was carried out on the girl-mentees. Questions addressed include the challenges and the 
benefits of using platform, should mentoring be included in the curriculum? What the influence of parents should be in a mentoring relationships and others.

Mobile based mentoring platform - The Mobile-based Mentoring Platform is designed and developed to provide on-the-go mentoring for girls. Girls were mentored on issues that relate to academic performance, self-esteem and confidence, development general life skills, better relations with peers, teachers, and other people in school, how to avoid classroom disruptions, fighting, and other negative school behavior, sexuality issues and postsecondary education, job placement or career exploration. The platform is also created to support Progressive Web App (PWA). The web pages appear like traditional applications or native mobile applications to users. The platform is domicile on www.gcmentoringinitiative.org. Mentors and mentees are not bound by time and space because interactions take place on the platform via mobile devices.

\section{Figure 1}

\section{Components interaction on the platform}

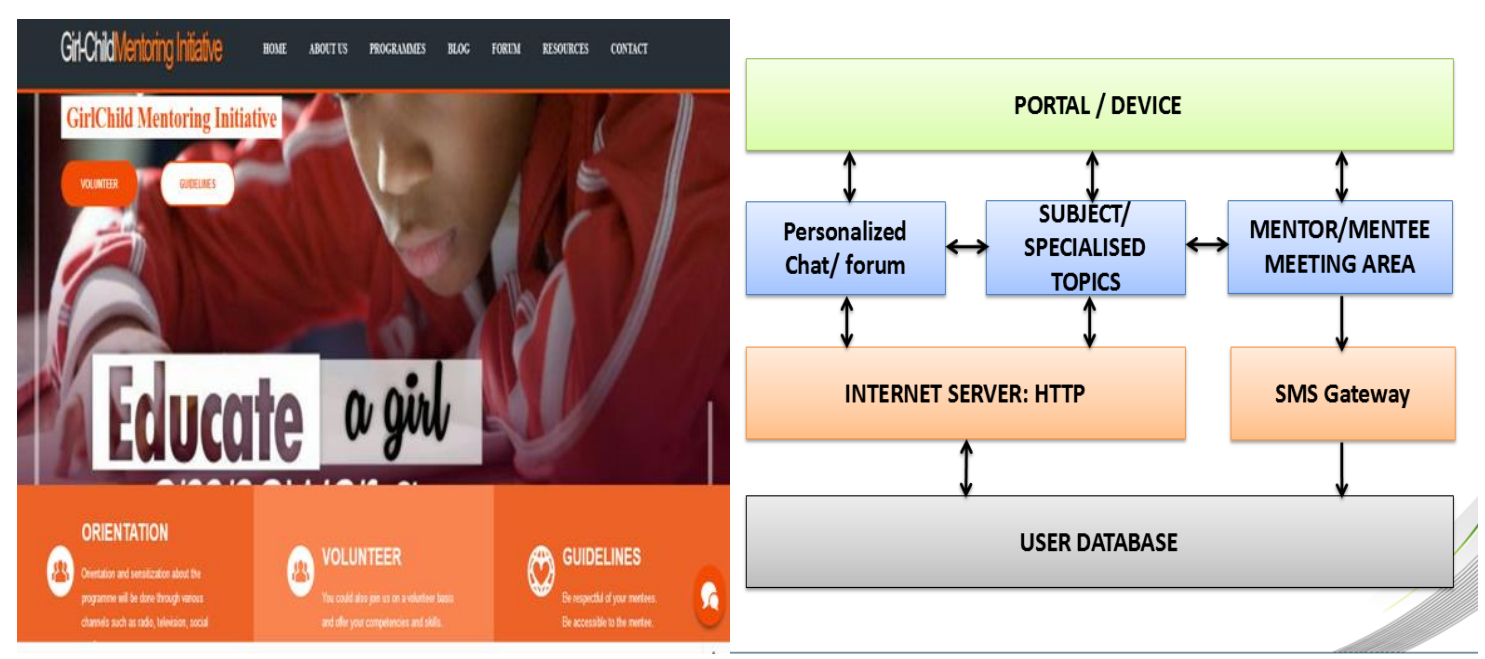

\section{Selection of Participants and Sampling Technique}

The researchers adopted purposive sampling technique to select the schools and numbers of students to participate in the study. The criteria used to select mentees were based on the girl's willingness to participate in the study and their parents' consent to allow them participate. The sample size that was used for this study consists of forty (40) girls in senior 
secondary school one (S.S.S 1). Twelve (12) mentors were selected based on their willingness to participate in the study, ownership of web-enabled phones or device, and being an undergraduate student in a Nigeria Higher Institution.

\section{Method of Data Analysis}

Content analysis was carried on the information obtained from the Focus Group Discussion (FGD). FGD was used to gather data because the mentees were able to discuss their thoughts freely. The discussions generate ideas that can provide a wealth of information about mentees' perspective, biases and opinions about the program. The answers from the FGD sessions were grouped, organized and classifies into categories.

\section{Procedure}

Mentors were trained on how the platform works and how to use their mobile device to access it. Mentors and mentees were not bound by time and space because interactions took place on the platform via mobile devices. Mentors were trained on what their attitude and conduct towards the mentees should be. Conduct of both mentor and mentee were clearly stated in the guideline section on the platform. Orientation and sensitization about the mentoring program were done through various channels such as visitation to schools, social media, one-on-one contact, the internet, giving leaflets to various stakeholders, organizing town meetings, meetings with community and religious leaders and local government officials.

\section{Results}

Table 1:

Showing the benefits of mobile-based mentoring

\begin{tabular}{|c|l|l|}
\hline $\mathbf{S} / \mathbf{N}$ & & Summary of Comments \\
\hline 1. & $\begin{array}{l}\text { I enjoyed being mentored via } \\
\text { the platform } \\
\text { (www.gcmentoringinitiative.org) }\end{array}$ & $\begin{array}{l}\text { The mentees commented } \\
\text { that being able to share } \\
\text { their successes, personal } \\
\text { struggles, learning } \\
\text { difficulties, ideas, and other } \\
\text { challenges with someone } \\
\text { who understands them and } \\
\text { is always ready to listen } \\
\text { would help them } \\
\text { understand life more and be }\end{array}$ \\
\hline 2. & $\begin{array}{l}\text { I enjoy discussing with my } \\
\text { mentor on the platform }\end{array}$ & \multicolumn{2}{|c|}{} \\
\hline
\end{tabular}




\begin{tabular}{|c|c|c|}
\hline & & $\begin{array}{l}\text { emotionally balanced to } \\
\text { undertake diverse issues } \\
\text { their academics and } \\
\text { personal lives. } \\
\text { The platform provided a } \\
\text { relaxing environment to be } \\
\text { able to discuss with the } \\
\text { mentors anytime they want } \\
\text { to }\end{array}$ \\
\hline 3. & $\begin{array}{l}\text { The mentoring platform exposed } \\
\text { me to learning many new things } \\
\text { that I do not know before }\end{array}$ & $\begin{array}{l}\text { The mentors were able to } \\
\text { provide various learning } \\
\text { opportunities and useful } \\
\text { advice on academics } \\
\text { especially subjects they } \\
\text { have difficulties in } \\
\text { understanding. } \\
\text { mentors provide URLs and } \\
\text { other learning resources for } \\
\text { easy comprehension of } \\
\text { concepts }\end{array}$ \\
\hline 4. & $\begin{array}{l}\text { I feel comfortable being } \\
\text { mentored on the platform } \\
\text { because I will be able to ask } \\
\text { questions I would not have asked } \\
\text { face-to-face }\end{array}$ & $\begin{array}{l}\text { Participants indicate that } \\
\text { having access to their } \\
\text { mentors every time through } \\
\text { the platform helps build } \\
\text { trust easily and can ask } \\
\text { personal questions anytime } \\
\text { such occasion arises. }\end{array}$ \\
\hline 5. & $\begin{array}{l}\text { Immediate response makes } \\
\text { interactions effective }\end{array}$ & $\begin{array}{l}\text { Mentees say that the } \\
\text { opportunity to get } \\
\text { immediate response from } \\
\text { mentors on their questions } \\
\text { makes relating with them } \\
\text { interesting. It makes it easy } \\
\text { for them to share } \\
\text { information and they are } \\
\text { also motivated to express } \\
\text { themselves. }\end{array}$ \\
\hline 6. & $\begin{array}{l}\text { I believe there are many things I } \\
\text { know now because of mentoring } \\
\text { on the platform. }\end{array}$ & $\begin{array}{l}\text { Mentees believed that they } \\
\text { have been more exposed to } \\
\text { diverse issues, they } \\
\text { believed they are well } \\
\text { informed and mentors have } \\
\text { guided them through some } \\
\text { tough decisions }\end{array}$ \\
\hline 7. & $\begin{array}{l}\text { I like to be mentored on the } \\
\text { platform but I do not have the } \\
\text { resources }\end{array}$ & $\begin{array}{lcr}\text { Mentees implored } & \text { their } \\
\text { school leaders } & \text { and } \\
\text { administrators to make }\end{array}$ \\
\hline 8 & Mentoring has benefited me & $\begin{array}{l}\text { formal mentoring a core } \\
\text { aspect of their curriculum. } \\
\text { Through the mentoring }\end{array}$ \\
\hline
\end{tabular}




\begin{tabular}{|l|l|}
\hline & $\begin{array}{l}\text { program, they now have } \\
\text { positive outlook to life, } \\
\text { more proactive approach to } \\
\text { their academics, they also } \\
\text { believe that the program } \\
\text { has improved the self- } \\
\text { esteem and confidence. }\end{array}$ \\
\hline
\end{tabular}

Table 2:

Showing the challenges of mobile-based mentoring

\begin{tabular}{|c|l|l|}
\hline $\mathbf{S} /$ & & Summary of Comments \\
\hline 1 & $\begin{array}{l}\text { Preference for Face-to-face } \\
\text { mentoring }\end{array}$ & $\begin{array}{l}\text { Some mentees parents } \\
\text { monitor their } \\
\text { conversations, this makes } \\
\text { some of the mentees not } \\
\text { to completely open-up } \\
\text { during discussions on the } \\
\text { platform, some requested } \\
\text { for a face-to-face meeting } \\
\text { with mentors. }\end{array}$ \\
\hline 2 & $\begin{array}{l}\text { Insecurity during discussing } \\
\text { personal issues via mobiles }\end{array}$ & $\begin{array}{l}\text { Mentees would sometimes } \\
\text { want to know if their } \\
\text { discussions with mentors } \\
\text { are recorded or multiple } \\
\text { individuals are responding } \\
\text { to them. This caused a bit } \\
\text { of edginess among some } \\
\text { mentees }\end{array}$ \\
\hline 3 & $\begin{array}{l}\text { Usefulness of Mobile mentoring } \\
\text { for my level }\end{array}$ & $\begin{array}{l}\text { Some parents felt the } \\
\text { mentoring platform should } \\
\text { be used for mentees in } \\
\text { higher education only }\end{array}$ \\
\hline 5 & $\begin{array}{l}\text { Navigational issues on the } \\
\text { platform }\end{array}$ & $\begin{array}{l}\text { Some mentees needed } \\
\text { technical support to } \\
\text { navigate through the } \\
\text { platform mobiles for mentoring }\end{array}$ \\
\hline $\begin{array}{l}\text { Some mentees still } \\
\text { complained about the high } \\
\text { cost of internet, a major } \\
\text { mobile internet provider } \\
\text { that the mentees use } \\
\text { (MTN) increased the price } \\
\text { of internet from N1000 } \\
\text { for 1.5Gg to N1200 for } \\
\text { 1Gg day and 500mb from } \\
\text { 1am to 7am). Even with }\end{array}$ \\
\hline
\end{tabular}




\begin{tabular}{|c|l|l|}
\hline & & $\begin{array}{l}\text { other internet providers, } \\
\text { the mentees had the same } \\
\text { complaint. }\end{array}$ \\
\hline 6 & $\begin{array}{l}\text { Getting distracted when using the } \\
\text { platform for a long time }\end{array}$ & $\begin{array}{l}\text { Some mentees complained } \\
\text { that they lose focus and } \\
\text { track of discussions easily } \\
\text { when they discuss with } \\
\text { mentors }\end{array}$ \\
\hline 8 & $\begin{array}{l}\text { Money to purchase internet } \\
\text { access inability to have constant } \\
\text { access to a phone made } \\
\text { mentoring on the platform } \\
\text { difficult for me }\end{array}$ & $\begin{array}{l}\text { Some mentees complained } \\
\text { that they cannot discuss } \\
\text { with mentors as often as } \\
\text { they would have wished } \\
\text { because of inadequate } \\
\text { access to internet or } \\
\text { money to purchase } \\
\text { internet bundles. Some of } \\
\text { them had to use their } \\
\text { sisters, brothers or parents } \\
\text { mobile phones to access } \\
\text { the platform. This } \\
\text { hampered their } \\
\text { discussions with the } \\
\text { mentors. }\end{array}$ \\
\hline
\end{tabular}

\section{Discussion}

Focus Group Discussion (FGD) guide was used to obtain information about the girlmentees' opinions and comments concerning the benefits of using the platform for mentoring purpose and the challenges they faced in the process. The mentees explained that using the platform allows them to have access to their mentors at any time and gives them ample time to discuss with them. They indicated that the idea of building relationships with mentors using the platform saves time. Some of the comments of the mentees include being able to receive adequate guidance and support in their academics and pressing personal issues. "When I do not understand something, I simply ask my mentor and get a prompt response", "I know more about some consequences of engaging in pre-marital sex now." Others are: "I have someone that I can call my friend, she seems to know about everything and I can trust her to help me through this stage of life," "using the platform is practical and it is a less stressful way of communicating with my mentor, I can pick up my phone at any time to discuss with her - It is quite easy for me". The mentees also indicated that they 
could receive an easy access to learning resources and share ideas and opinions with other mentees through the forum sections.

Focus Group Discussion (FGD) guide was used to obtain information about the mentees' opinions and comments about challenges they faced while being mentored on the mentoring platform. The mentees commented that the home environment is sometimes not motivating and attractive enough for serious mentoring to be done using a mobile-based platform. They complained about the high cost of smartphones, and some of them had to use the devices of their parents, sisters or brothers. They reiterated further by saying that mentors and mentees must possess these phones for mobile learning to be effective. Others challenges identified are: epileptic network/internet and the prohibitive cost of internet subscription.

However, the students noted that school administrators should make formal mentoring using Information and Communication Technology (ICT) to be a core aspect of the curriculum. Also, mobile-based mentoring is considered efficacious because the mentees were free to ask questions and discuss issues they would not have discussed if they were mentored face-to-face. Mentees are not forced to talk, they were free to make their opinion including their likes and displeasures. Online mentoring has been found to be very advantageous in the context of general life skill development, right relationships and career (Herrington and Kew, 2009). Mentees, also, benefit from the mentor as regards their psychosocial and career development, mentoring could be a predictor of career outcomes (Griffiths, and Miller, 2005).

\section{Conclusions}

While many girls and women have faced tremendous abuse that has affected their emotional and psychological stability, education and career pursuit, and others, their strategic role in the overall growth and development of a nation cannot be emphasized. To ensure equality and balanced human capital, attention must be paid to the girl-child's educational and psychological development. Mentoring provides a means where mentors can create a less intimidating environment where girl-mentees can develop a sense of selfworth, grow emotionally and academically. Mobile technologies provide a unique opportunity for girl-mentees to have on-the-go access to their mentors. The mentors inspire and nurture the girls' competencies - this is the hallmark of the mobile-based mentoring platform. The platform was developed to help girl-mentees access advice on academics, 
personal and sexual life, general life skills, relationships with parents and friends, and others. The general comments of mentees about mobile-based mentoring include; prompt access to mentors and valuable resources, schools should include formal mentoring into the curriculum, and others. They also expressed frustration over the cost of the internet and the epileptic internet network, mentees sometimes request for a face-to-face session because their parents always want to know what is being discussed. In the light of these findings, mentoring can be a useful tool in girls' all-around development; therefore, formal mentoring using a socio-cultural relevant online/mobile platform should be adopted by schools. Problems associated with implementing the project include parents objecting to the children participating, citing privacy and security concerns. Some mentees complained that the platform is complex to use. This prompted several adjustments to be made on the platform to make it easy to use. The next stage of the project is to design an offline mentoring platform to cater for girls that have devices but have difficulties accessing the internet. Interactions will be predicated on Short Messing Service and other offline protocols

\section{References}

Abimbade, O., Adedoja, G., Fakayode, B., \& Bello, L. (2019). Impact of mobile-based mentoring, socio-economic background and religion on girls' attitude and belief towards antisocial behaviour (ASB). British Journal of Educational Technology, $50(2), 638-654$.

Abimbade, O., Akinyemi, A., Bello, L., \& Mohammed, H. (2017). Comparative Effects of an Individualized Computer-Based Instruction and a Modified Conventional Strategy on Students' Academic Achievement in Organic Chemistry. Journal of Positive Psychology and Counseling, 1(2), 1-19.

Adedoja, G., \& Abimbade, O. (2013, May). Social studies teachers' intention to use mobile phones as a support and tutorial tool for teaching. In 2013 IST-Africa Conference \& Exhibition (pp. 1-8). IEEE.

Adedoja, G., \& Oluwadara, A. (2016). Influence of Age and Training on Planning Instruction Using Mobiles Phones by Pre-service Social Studies Teachers. Science and Education, 3(1), 1-6.

Adedoja, G., Abimbade, O., Akinyemi, A., and Bello, L. (2017). Discovering the Power of Mentoring using Online Collaborative Technologies. In C.O.O Kolawole, R.O. Akinbote, T.A. Ige, G. Adedoja, and A. Aremu (Eds.). Advancing Education through Technology. Ibadan His Lineage Publishing House. Pp. $261-281$.

Esobi, I. C., Lasode, M. K., Anyanwu, C. I., Barriguete, M. F., Okorie, M. A., \& Lasode, D. O. (2021). Food Insecurity, Social Vulnerability, and the Impact of COVID-19 
on Population Dependent on Public Assistance/SNAP: A Case Study of South Carolina, USA. Journal of Food Security, 9(1), 8-18.

Esobi, I. C., Lasode, M. K., Anyanwu, C. I., Degbe, E., Barriguete, M. F., Okorie, M. A., ... \& Okegbe, S. (2020). Nutritional Impact of COVID-19 and Its Implications on Atherosclerosis. World, 8(1), 16-21.

Esobi, I. C., Lasode, M. K., \& Barriguete, M. F. (2020). The Impact of COVID-19 on Healthy Eating Habits. J Clin Nutr Heal, 1(1), 001-002.

Fakayode, B. (2017). Impacts of mobile-based mentoring on girl's attitude towards antisocial behaviours among secondary school students in Ibadan. Oyo state. Unpublished M.Ed. Dissertation in Educational Technology. Faculty of Education. University of Ibadan.

Fisho-Orideji D. (2001) The Girl-child: Developing the Potentials of Girl-child a National Challenge

Foster, W. R., Poole, J. H, and Coulson-Clark, M. M. (2001). Faculty mentoring in higher education: Hype or help. Leadership Advance Online. Retrieved March 29, 2006, fromhttp://www.regent.edu.acad/sis/

publications/journals/leadershipadvance/pdf_20002001/foster_faculty_mentoring.pdf

Galbraith, M. W. (2001). Mentoring development for community college faculty. The Michigan Community College Journal, 29-39.

Griffiths, M.D. and Miller, H.M. (2005). E-mentoring in schools: A brief review. Education and Health, 23, 6-8

Herrington M, Kew J, and Kew P. (2009). Global Entrepreneurship Monitor, South African Report.

(Online).Available:http://www.gbs.nct.ac.za/gbswebb/userfiles/gemsouthafrica2 $\underline{000 \mathrm{pdf}}$.

Igube, R.B. (2004). Gender Security and Advancement: the Case of Inequality and Inequity. Paper Presented at the Round Table Discourse by Higher Link Educational Programme, The British Council, Change Managers International, University of Abuja, Abuja 8th march, 2004.

Lasode, M., Esobi, I., Anyanwu, C., \& Lasode, D. (2020). Assessing Urban Land use Change in New Braunfels, Texas from 2013 to 2020.

Matthews, P. (2003). Academic mentoring. Enhancing the use of scarce resources. Educational Management \& Administration, 31 (3), 313-334.

Offorma, G.C. (2008). The Boy-child-education in the South-eastern States of Nigeria: Problems and Prospects. Paper Presented at the Convention of the Unity Schools Old Students Association (USOSA), held at Dannic Hotel, Enugu. 
Okpani, A. (2002). Sexuality activity and contraceptive use among adolescents in Rivers State of Nigeria: Rationale, Benefits and Opportunities. Port-Harcourt.

Oluwadara, A., Kolapo, B. L., \& Esobi, I. C. (2020). Designing a Framework for Training Teachers on Mobile Learning in Sub-Sahara Africa.

Oluwaseun, O., Tolulope, F., Lukuman, B., \& Ikechukwu, E. C. (2020). Improving Preservice Teachers' Memory and Retention Using Durable Memory Strategies in an Instructional Technology Course. American Journal of Educational Research, 8(11), 847-855.

Osakwe, E. O. (1993). Social Studies for Tertiary Student in Nigeria. Enugu: New Age Publishers.

Plan Canada (2015). http://plancanada.ca/violence-in-schools-education-for-girls. Violence keeping children out of school, especially girls. Retrieved on 8/22/16

The United Nations Fourth Conference on Women, Beijing. (1995). Action for Equality, Development and Peace

World Health Organization (2004). Adolescent sexual and reproductive health. www.who.int/maternal_child_adolscent/documents/adolescent/en/ 